\title{
General Comment
}

\section{Respect voor jonge kinderen als dragers van kinderrechten: General Comment No. 7 nader beschouwd}

\author{
Mr. M.M.C. Limbeek*
}

Het VN-Kinderrechtencomité heeft als taak de naleving van kinderrechten, zoals vastgelegd in het Internationaal Verdrag inzake de Rechten van het Kind, te controleren. Landen die partij zijn bij het Verdrag zijn verplicht iedere vijf jaar te rapporteren aan het $\mathrm{VN}$-Kinderrechtencomité over de kinderrechtensituatie in hun land. Daarnaast vaardigt het Kinderrechtencomité General Comments uit, waarin het duiding geeft aan bepaalde kinderrechten(thema's). Op dit moment zijn 21 General Comments gepubliceerd die betrekking hebben op onder andere het jeugdstrafrecht (No. 10), de adolescentie (No. 20), de belangen van het kind (No. 14) en het recht op bescherming tegen geweld (No. 13). In deze rubriek wordt steeds één General Comment uitgelicht.

In deze bijdrage wordt stilgestaan bij General Comment No. $7,{ }^{1}$ waarin het implementeren van kinderrechten in de vroege kinderjaren centraal staat. Allereerst wordt ingegaan op de vraag waarom het VN-Kinderrechtencomité het nodig achtte om dit General Comment op te stellen. Daarna wordt ingezoomd op de aanbevelingen

* Mr. M.M.C. Limbeek is adviseur en portefeuillehouder jeugd bij de Raad voor Strafrechtstoepassing en Jeugdbescherming. Ze schrijft deze bijdrage op persoonlijke titel.

1. General Comment No. 7 (2005), Implementing child rights in early childhood, te raadplegen via de officiële website van het VN-Kinderrechtencomité: https://www.ohchr.org/EN/HRBodies/CRC/Pages/ CRCIndex.aspx. van het comité met betrekking tot het respect voor de mening van jonge kinderen, de ouderlijke verantwoordelijkheid en passende hulp aan ouders. De bijdrage wordt afgesloten met een nawoord waarin de kernboodschap van het comité wordt samengevat en de vraag wordt gesteld of deze boodschap nog steeds van belang is.

\section{Aanleiding en doel}

In 2003 besloot het VN-Kinderrechtencomité dat de eerstvolgende Day of General Discussion (hierna: DGD) in 2004 gewijd moest worden aan het thema 'Implementing child rights in early childhood'. ${ }^{2}$ Het comité koos voor dit thema omdat landenrapportages in veel gevallen in beperkte mate informatie verschaften over de implementatie van de rechten van jonge kinderen. In dialoog met lidstaten ervaarde het comité dat jonge kinderen met name gezien worden als 'voorwerp van zorg' en dat men zich te weinig bewust is van het feit dat jonge kinderen ook dragers van rechten zijn. De constatering dat een 'full respect for young children as rights-holders' ontbrak, was dan ook de hoofdreden waarom het comité door middel van discussie bewustwording wilde creëren over de bredere implicaties van het Internationaal verdrag inzake de Rechten van het Kind (hierna: IVRK) voor jonge kinderen. ${ }^{3}$

2. A Guide to General Comment 7: 'Implementing Child Rights in Early Childhood' (2006), p. 31.

3. General Comment No. 7 (2005), para. 1; A Guide to General Comment 7: 'Implementing Child Rights in Early Childhood' (2006), p. 31-32. 
De discussie die volgde, in het kader van de DGD op 17 september 2004, resulteerde in een set aanbevelingen en in het besef dat het thema verder moest worden uitgewerkt in een General Comment om lidstaten te voorzien van meer gedetailleerde informatie en advies over de implementatie van kinderrechten in de vroege kinderjaren. ${ }^{4}$ In de navolgende maanden hebben experts vanuit verschillende disciplines (o.a. onderwijs, ontwikkelingspsychologie, gezondheid, rechten en sociologie) input geleverd. $\mathrm{Na}$ een uitgebreide consultatieronde werd de definitieve tekst van het General Comment op 30 september 2005 aangenomen.

In de introductie bij het General Comment benadrukt het comité dat de vroege kinderjaren een belangrijke ontwikkelingsperiode is voor het realiseren van kinderrechten. Met vroege kinderjaren ('early childhood') worden kinderen in de leeftijd vanaf nul tot aan de basisschoolleeftijd bedoeld. Omdat in sommige landen kinderen pas rond zeven jaar naar school gaan, hanteert het comité een werkdefinitie die ziet op alle kinderen onder de acht jaar.

Het General Comment noemt zeven doelstellingen. Een van de zeven doelstellingen van het General Comment is bijvoorbeeld dat jonge kinderen erkend worden als sociale actoren vanaf het begin van het leven, met hun eigen interesses, capaciteiten en kwetsbaarheden en daarbij passende bescherming, begeleiding en ondersteuning bij de uitoefening van hun rechten. ${ }^{5}$ Meer fundamenteel is het doel van het comité om met dit General Comment nadruk te leggen op het feit dat ook jonge kinderen dragers van rechten zijn. ${ }^{6}$

\section{Respect voor de mening van jonge kinderen}

Het comité benadrukt dat - ook - jonge kinderen het recht hebben om hun mening te geven over zaken die hen betreffen. ${ }^{7}$ Daarnaast hebben jonge kinderen er recht op dat hun mening al naar gelang hun leeftijd en rijpheid in overweging wordt genomen:

'As holders of rights, even the youngest children are entitled to express their views, which should be given due weight in accordance with the age and maturity of the child' (art. 12 lid 1 IVRK).

Jonge kinderen zijn volgens het comité goed in staat om hun omgeving te begrijpen. Ze maken keuzes en geven op verschillende manieren aan wat zij voelen en welke wensen en ideeën zij hebben, al veel eerder dan dat zij

4. A Guide to General Comment 7: 'Implementing Child Rights in Early Childhood' (2006), vii.

5. General Comment No. 7, para. 2

6. A Guide to General Comment 7: 'Implementing Child Rights in Early Childhood' (2006), p. 32.

7. General Comment No. 7, para. 14. communiceren via de voor volwassenen gebruikelijke (schrijf)taal. ${ }^{8}$

Om deze reden wil het VN-Comité lidstaten aanmoedigen om met passende maatregelen en in een zo vroeg mogelijk stadium te waarborgen dat het kind als drager van rechten gezien wordt, dat het de vrijheid heeft om zijn mening te geven en het recht heeft om daarover op passende wijze geconsulteerd te worden in zaken die op hem betrekking hebben.

Dit recht van jonge kinderen om hun mening en gevoelens te uiten zou verankerd moeten worden in het dagelijks leven van het kind. Dit betekent dat dit recht niet alleen gedurende juridische procedures in acht genomen moet worden maar ook thuis, bij de kinderopvang, in de zorg, op school en bij het ontwikkelen van beleid, voorzieningen en onderzoek.

Hier ligt ook een taak voor lidstaten om actieve betrokkenheid van ouders, professionals en de verantwoordelijke overheidsorganen aan te moedigen bij het creëren van mogelijkheden voor jonge kinderen om steeds meer hun rechten te kunnen uitoefenen in alle facetten van het dagelijks leven.

Het recht van het kind om te participeren, vereist van volwassenen een houding die het kind centraal stelt. Dit centraal stellen van het kind betekent dat volwassenen luisteren naar jonge kinderen en respect hebben voor hun waardigheid en hun persoonlijke mening. Dit vereist van volwassenen geduld en creativiteit om aan te kunnen sluiten bij de belevingswereld van jonge kinderen.

\section{Ouderlijke verantwoordelijkheid}

In de zienswijze van het comité spelen ouders een cruciale rol in het verwezenlijken van de rechten van (jonge) kinderen. ${ }^{9}$ Van ouders, en andere primaire verzorgers, wordt verwacht dat het belang van het kind hun allereerste zorg is. ${ }^{10}$ De rol van de ouders bestaat uit het bieden van passende aanwijzingen en begeleiding bij de uitoefening van kinderrechten (art. 5 IVRK). Op deze manier spelen ouders (en andere verzorgers) een sleutelrol om jonge kinderen in staat te stellen hun rechten te realiseren.

De zich ontwikkelende vermogens van het kind ('evolving capacities') maken het mogelijk dat kinderen steeds meer zelf hun rechten kunnen realiseren. Ouders en anderen zullen zich dan ook voortdurend dienen aan te passen. ${ }^{11}$ Lidstaten dienen de rol van de ouders te respecteren. ${ }^{12}$ Daarbij hoort ook dat ouders en (jonge) kinderen niet worden gescheiden, tenzij dit in het belang

8. General Comment No. 7, para. 14

9. General Comment No. 7, para. 15.

10. General Comment No. 7, para. 16

11. General Comment No. 7, para. 17.

12. General Comment No. 7, para. 18. 
van het kind is (art. 9 IVRK). Jonge kinderen zijn extreem kwetsbaar voor de negatieve gevolgen die een scheiding met zich mee kan brengen. Dit komt door hun nog grote fysieke en emotionele afhankelijkheid van hun ouders.

\section{Passende hulp aan ouders}

Lidstaten zijn verplicht om ouders passende bijstand en hulp te bieden als dat nodig is. Het comité noemt verschillende directe en indirecte maatregelen waaraan lidstaten kunnen denken, zoals kinderbijslag en verloskundige zorg. ${ }^{13}$ Passende hulp aan ouders kan volgens het comité het beste worden bereikt als onderdeel van alomvattend beleid voor vroege kinderjaren (zie deel $\mathrm{V}$ in het General Comment), inclusief voorzieningen voor gezondheid, zorg en onderwijs in de beginjaren. ${ }^{14}$ Bijzondere aandacht dient daarbij uit te gaan naar de meest benadeelde en kwetsbare groepen, zoals (jonge) kinderen die leven in armoede, kinderen uit migrantenfamilies, kinderen met beperkingen, kinderen die behoren tot minderheidsgroeperingen, weeskinderen, kinderen die leven in instellingen, vluchtelingkinderen en kinderen met ouders met een alcohol- of drugsprobleem. ${ }^{15}$

\section{Nawoord}

De vroege kindertijd, de periode tot acht jaar, is een cruciale periode voor de ontwikkeling van het kind en voor het realiseren van kinderrechten. Elk kind is een unieke deelnemer aan de samenleving, niet slechts een object van zorg, maar ook een drager van rechten. Goed luisteren naar kinderen en respect hebben voor hun waardigheid en persoonlijke mening, dat is de kernboodschap van het VN-Kinderrechtencomité in dit General Comment No.7, Implementing child rights in early childhood.

Deze kernboodschap is gericht aan ouders en aan alle andere volwassenen die in het dagelijks leven met jonge kinderen leven en werken. Idealiter zou dus iedereen die verantwoordelijk is voor de zorg en/of ontwikkeling van jonge kinderen een omgeving moeten creëren waarin jonge kinderen zich uitgenodigd voelen om hun mening te geven. Het comité heeft op deze wijze meer in brede zin willen benadrukken dat de rechten van jonge kinderen in alle facetten van het dagelijks leven gerealiseerd moeten worden.

Het zijn in de beginfase vooral de ouders en andere primaire verzorgers die een belangrijke rol spelen in het realiseren van de kinderrechten van jonge kinderen. Naarmate het kind zich verder ontwikkelt, geven de

13. General Comment No. 7, para. 20

14. General Comment No. 7, para. 21

15. General Comment No. 7, para. 24 ouders en anderen het kind meer ruimte om kinderrechten zelf te realiseren. Zowel ouders, professionals en verantwoordelijke overheidsorganen moeten worden aangemoedigd in het creëren van mogelijkheden voor jonge kinderen om hun rechten te kunnen uitoefenen. Hier ligt volgens het comité een taak van de overheid.

Dat de boodschap van het Kinderrechtencomité nog steeds van belang is, onderschrijft het proefschrift van Ganna van Bijleveld. ${ }^{16}$ Ondanks dat uit wetenschappelijk onderzoek bekend is dat het betrekken van kinderen in de besluitvorming hen helpt in hun ontwikkeling en bijdraagt aan beter passende interventies, blijft het voor sommige (jeugd)professionals in de praktijk moeilijk om (jonge) kinderen hierbij te betrekken. Daarom blijft het van belang dat jonge kinderen gezien worden als dragers van kinderrechten. Dit vraagt van ouders, medeopvoeders, (jeugd)professionals en overheidsorganen bewustwording van hun eigen rol en verantwoordelijkheden in het realiseren van kinderrechten van jonge kinderen.
16. G.G. van Bijleveld, Dealing with the interplay of child image, protection and participation: A critical reflection on the essence of child participation in child protection services (diss. Amsterdam VU), 2019. 